\title{
THE ACCESS TO FINANCE BY SMES IN TURKEY AND THE EU: A COMPARATIVE STUDY
}

\author{
DOI: 10.17261/Pressacademia.2019.1133 \\ PAP-IFC- V.10-2019(1)-p.1-6
}

\section{Muhammed Kahraman'1, Arzu Tektas², Ali Coskun ${ }^{3}$}

${ }^{1}$ Boğaziçi University, Institute for Graduate Studies in Social Sciences, International Trade Department, Istanbul, Turkey. muhammed.kahraman1@istanbul.edu.tr, ORCID: 0000-0002-3342-7751

2Boğaziçi University, Institute for Graduate Studies in Social Sciences, International Trade Department, Istanbul, Turkey. tektas@boun.edu.tr, ORCID: 0000-0003-4631-6310

${ }^{3}$ Boğaziçi University, Institute for Graduate Studies in Social Sciences, Business Administration Department, Istanbul, Turkey. ali.coskun@boun.edu.tr, ORCID: 0000-0003-1723-1107

\section{To cite this document}

Kahraman M., Tektas A., Coskun A. (2019). The access to finance by SMSs in Turkey and the EU: acomparative study. PressAcademia Procedia (PAP), V.10, p.1-6.

Permemant link to this document: http://doi.org/10.17261/Pressacademia.2019.1133

Copyright: Published by PressAcademia and limited licenced re-use rights only.

\begin{abstract}
Purpose-Access to finance is one of the major factors in the growth of Small and Medium-sized Enterprises (SMEs), which comprise $99 \%$ of companies in Turkey and the EU and have a large impact on GDP and unemployment. Therefore, the purpose of this study is to compare status and changes in the access to finance of SMEs in Turkey and the EU. And additionally, to evaluate the access to finance of Turkish SMEs according to their associate status, location, business area, exports, liquid assets, and establishment time.

Methodology- In developing the questionnaire used in this survey, some of the questions from the Survey on the Access to Finance of Enterprises (SAFE 2017) conducted in October 2017 on the EU SMEs, were modified. The questionnaire was sent to SMEs in Turkey through KOSGEB (Small and Medium-Sized Enterprises Development and Support Agency (Küçük ve Orta Ölçekli iş̧letmeleri Geliştirme ve Destekleme idaresi Başkanlığı)) via e-mail. The response percentages obtained were compared with the response percentages from SAFE 2017. Also using analyses such as chi-square and multiple regression (SPSS) significant relations between answers of Turkish SMEs were determined.

Findings- According to the results of the questionnaire conducted and SAFE 2017, the second biggest issue for SMEs in Turkey is the access to finance, while this issue is the least important for SMEs in the EU; the increase in availability of financial sources for SMEs in the EU is much larger and they use them mostly for new investments, while SMEs in Turkey use them mostly for inventories; expenses for SMEs in Turkey such as labor and raw material cost increased more, which probably led to a decrease in profit and an increase in debts. According to multiple regression and chi-square analysesata5\% significance level, it is found that the amount of credit received by SMEs in Turkey, and the usage of loans from family and friends are significantly affected by the age, number of employees, turnover level, export level, business area, and geographical location of the company. The usage of government loans and incentives by SMEs in Turkey is significantly affected by age, the number of employees, and the export level of the company. The usage of bank loans by SMEs in Turkey is significantly affected by the age, turnover level, export level, and the number of employees of the company. The usage of leasing and trade credits by SMEs in Turkey is significantly affected by the age, the number of employees, turnover level, export level, business area, geographical location, and the partnership status of the company.

Conclusion-There is a limited number of studies focusing on access to finance for SMEs in Turkey. They mostly tend to concentrate only on problematic supply-side factors and miss to show the significant relationship between demand-side factors, meaning SMEs' characteristics, and access to finance. At the same time, to our best knowledge, there is not any study directly comparing Turkish SMEs to the European SMEs except SAFE reports, which take only 300 SMEs in Turkey into consideration. On the other hand, this study takes 1,518 SMEs in Turkey into consideration and compares SMEs in Turkey and the EU according to their characteristics and access to finance.
\end{abstract}

Keywords: Small and Medium-sized Enterprises, SMEs, access to finance, Turkey, European Union JEL Codes: M10, G40

\section{INTRODUCTION}

SMEs have a very important role in the economies of all countries worldwide. They can positively affect the growth and gross domestic product (GDP), create employment and income opportunities, and even lead to social cohesion. There are numerous studies showing that one of the major obstacles in front of the growth of SMEs worldwide is access to finance (Boachie-Mensah \& Marfo-Yiadom, 2006; Organization for Economic Co-operation and Development (OECD), 2004; Beck, Demirguc-Kunt \& Maksimovic, 2004). The Global Competitiveness Report (2018) lists Turkey at very low, 86th place among 140 countries surveyed, in the context of financing of SMEs. 
In this study, in order to analyze the access to finance of SMEs in Turkey and compare it to the EU situation, the questionnaire used comprises of questions selected from the SAFE 2017 conducted in October 2017 on SMEs in the EU. The rest of the paper is organized as follows: Section 2 provides a detailed literature survey on this topic. Section 3 explains the data and methodology while the results are presented in Section 4. Finally, Section 5 gives the conclusion.

\section{LITERATURE REVIEW}

SMEs in Turkey comprise $99.9 \%$ of all enterprises, $53 \%$ of salaries and wages, $76 \%$ of employment, $63 \%$ of turnover, and $53.7 \%$ of gross investment in physical goods. 62.6\% of exports in 2012 were from SMEs with 1-249 employees (Turkish Statistical Institute, 2013).

The capital structure represents the composition of one firm's capital with respect to various sources of funds (Gajurel, 2005). Many different factors can affect the selection of financing sources by a company. Some of them are the size of the firm, age of the firm, asset structure, growth, profitability, and firm risk (Titman \& Wessels, 1988; Abor, 2008). In the case of SMEs, other factors like location of the firm, industry, entrepreneur's gender and educational background, export level of the firm, and form of business might explain SMEs' capital structure (Abor, 2008). Kira (2013) showed that the industrial sector, age, incorporation, and ownership type are the most significant firm characteristics in access to finance for SMEs in East Africa. In addition, Wignaraja\&Jinjarak (2015) also found that export participation, age, foreign ownership, financial audit, managerial experience, industry and having ISO certificate determine the source of financing and kind of collateral in East Asia. According to Cakova and Önder (2011), the characteristics, like the industrial sector and size of the firm are significantly important when assessing the capital structure of Turkish SMEs.

One of the main factors that define the financial structure of a company is its age. Firm age has important effect on the firms' financing decisions and access to finance; therefore, there is a direct link in between the age of a firm and firm 's capital structure (Berger \&Udell, 1995; Bhaird\& Lucey, 2010). Abor and Biekpe $(2007,2009)$ and Abor (2008) detected a positive correlation between the long-term debt percentage and the age of the firm among SMEs. The study of Mahmud and Akin (2019) shows that the age of the Turkish SMEs has a significant impact on choosing short-term and long-term financing models. Older firms showed to be more dependent on bank financing and their dependence on the internal model of financing is reduced (Mahmud \& Akin, 2019). While discussing the age of the firms in Turkey, it would be appropriate to indicate that in Turkey, only $10 \%$ of established businesses last longer than three and a half years (WillisErtur\& Vader, 2015).

Jenkins et al. (2014) define the relationship between credit growth for SMEs and the fluctuating macroeconomic environment in Turkey. They show that an increase in the growth rate of GDP and rivalry in the Turkish banking sector affect positively the availability of bank loans to SMEs. Furthermore, alleviating the high inflation rate and decreasing government domestic borrowings significantly help enlarge SME bank credits likewise (Jenkins et al., 2014). Cakova and Önder (2011) also show that firms decrease their average debt ratios as the macroeconomic conditions improve in Turkey.

Export-oriented firms seem to have more trouble-free access to finance (Arráiz, Meléndez, \& Stucchi, 2011). Additionally, export processing zones will be more likely to get bank loans when compared with other locations (Ayyagari, Demirgüç-Kunt, \& Maksimovic, 2010).Ilgün and Muratovic (2013) show that most of the SMEs in Turkey will most likely fail to expand their market, especially internationally, due to the high costs of entering that market. Altintas and Ozdemir (2006) calculated the degree of internationalization for Turkish SMEs to be 1.622 on the scale of 5 , which is much lower than the average. When considering the use of financing sources according to the export level, Mahmud and Akin (2019) found that SMEs in Turkey with a higher share in exports rely less on their internal funds.

The location of the firm is another notable factor in SMEs' financial structure. Being far from the bank branches or financial centers is an important reason for not applying for a loan (Demirgüç-Kunt \& Klapper, 2012). There also happens to be a positive association between being near to banks and obtaining external finance, bank loan or any other (Abdulsaleh\& Worthington, 2013). Shinozaki (2012) also shows that urban SMEs record higher growth rates when compared to rural ones.

The ownership structure of the firm is another notable factor of SMEs' financial structure. Usually, incorporation is seen as a positive characteristic besides formality and credibility by banks and other finance institutions (Cassar, 2004). Most of the enterprises (80.6\%) in Turkey are operated by the owner of the enterprise (Ozar, 2004). The sole proprietorship proportion declines in the manufacturing sector and reaches its peak (73.4\%) in the hotels-restaurant sector (Ozar, 2004).

Sources of finance can be broadly grouped as internal or external sources of financing according to the place where it comes from. If the fund is taken from retained earnings, or the owners, it is called an internal source of finance (Holmes, Hutchinson, Forsaith, Gibson \& McMahon, 2003; Sarapaivanich, 2006). Among external sources of finance are informal sources like family and friends or business angels; and the formal ones like bank loans, trade credit, leasing, government schemes and venture capital (Ayadi, 2005; Kraemer-Eis\& Lang, 2012). Loans from family and friends are extensively used by SMEs, particularly at the start-up stage, when financial institutions do not provide funding due to the high risk involved (De la Torre, Martinez Peria \& Schmukler, 2010; OECD, 2004). Beck, Demirgüç-Kunt and Martínez Pería (2008) made a study on bank financing for SMEs based on 91 banks surveyed in 45 countries. They found that banks perceive the SME sector as highly profitable and try to serve it through numerous organizational setups and lending technologies. They reported that banks seem to reach out to SMEs according to their own status. Rocha, Farazi, Khouri, and Pearce (2011) studied the bank financing to SMEs in the regions of the Middle East and North Africa. Results show that the SMEs sector, although perceived as attractive, remains highly underserved.

In Turkey, most of the SMEs are dependent on bank financing. This dependence seems to be higher when compared to other countries (Şeker \& Correa, 2010). Trade credit seems to be the second most popular source of finance for Turkish SMEs (SAFE, 2013). Also, the most frequent type of non-bank financing is leasing, with SMEs comprising 40\% of leasing clients (OECD, 2016). At the same time, KOSGEB, a governmental institution for support of SMEs, offers grants and financial aid in few categories like project-based support, general support, 
loans of emergency support, entrepreneurship, and equipment and machinery support (Yagci, 2018). Some other alternative sources of finance for SMEs in Turkey include factoring, forfeiting, barter, venture capital, and international projects support (Ozer, 2016). However, most of the SME owners in Turkey do not have enough information on most of these alternative types of financing, utilization rate is very low, and they usually depend on family loan or a bank loan (Ozer, 2016).

\section{DATA AND METHODOLOGY}

The questionnaire used in this survey comprised of questions selected from the SAFE 2017 conducted in October 2017 on 11,202 SMEs in the EU. The questionnaire was emailed in June 2017 to the SMEs in Turkey through KOSGEB, a state institution in Turkey that is responsible for providing finance, incentives, and legal and logistical support to SMEs. It was answered by 1,518 firms. The results of the survey performed in this thesis were compared to the results of the SAFE 2017.Finally, the data collected from the survey performed in this thesis was evaluated for the presence of any relationship among answers to different questions in the questionnaire through chi-square and multiple regression analyses, using the SPSS software. All analyses were performed at a $5 \%$ significance level.

Statistical analyses are performed on collected results in order to see which independent variables, meaning SME characteristics, have a significant effect on the access to finance of SMEs. These independent variables are turnover level, age of the firm, export level, number of employees, associate status, geographical location, business area and purpose of using financial sources. Questions from which these variables are learned can be seen in Table 1 together with their possible answers.

Table 1: Independent SME Characteristics Studied in Multiple Regression and Chi-Square Analyses

\begin{tabular}{|l|l|l|l|l|l|l|l|l|}
\hline $\begin{array}{l}\text { Letter of } \\
\text { the } \\
\text { Answer }\end{array}$ & $\begin{array}{l}\text { Q1 } \\
\text { Associate } \\
\text { Status }\end{array}$ & $\begin{array}{l}\text { Q2 Activity } \\
\text { Area }\end{array}$ & $\begin{array}{l}\text { Q3 } \\
\text { Export }\end{array}$ & Q4 Region & $\begin{array}{l}\text { Q13 Turnover } \\
\text { Level }\end{array}$ & $\begin{array}{l}\text { Q14 } \\
\text { Age }\end{array}$ & $\begin{array}{l}\text { Q16 Purpose of } \\
\text { Using Financial } \\
\text { Sources }\end{array}$ & $\begin{array}{l}\text { Q17 } \\
\text { Employee } \\
\text { Number }\end{array}$ \\
\hline A & $\begin{array}{l}>50 \% \text { single- } \\
\text { owned }\end{array}$ & Building & None & Marmara & $<500,000$ TL & $<2$ & Fixed investment & $1-9$ \\
\hline B & Multi-owned & Industry & $<25 \%$ & $\begin{array}{l}\text { Central } \\
\text { Anatolian }\end{array}$ & $\begin{array}{l}500,000-1 \\
\text { million TL }\end{array}$ & $2-5$ & Inventory \\
\hline C & $\begin{array}{l}\text { Connected } \\
\text { (Turkish) }\end{array}$ & Trade & $\begin{array}{l}25 \%- \\
50 \%\end{array}$ & Black Sea & $\begin{array}{l}1 \text { million }-2 \\
\text { million TL }\end{array}$ & $5-10$ & Staff Education & $50-249$ \\
\hline D & $\begin{array}{l}\text { Connected } \\
\text { foreign) }\end{array}$ & Transport & $>50 \%$ & $\begin{array}{l}\text { Eastern } \\
\text { Anatolian }\end{array}$ & $\begin{array}{l}2,000,000- \\
10,000,000 ~ T L\end{array}$ & $>10$ & R \& D \\
\hline E & & Agriculture & & Aegean & $\begin{array}{l}10 \text { million }-50 \\
\text { million TL }\end{array}$ & & $>250$ \\
\hline F & & Finance & & Mediterranean & $>50$ million & & \\
\hline G & & & $\begin{array}{l}\text { Southeast } \\
\text { Anatolian }\end{array}$ & & \\
\hline
\end{tabular}

Dependent variables explored are the amount of the credit received and the usage of various financial sources by SMEs such ascredit from family and friends, government grants and incentives, bank loans, leasing, and trade credit. Questions from which these variables are learned can be seen in Table 2 together with their possible answers.

Table 2: Dependent Variables Studied in Multiple Regression and Chi-Square Analyses

\begin{tabular}{|c|c|c|c|c|c|c|}
\hline $\begin{array}{l}\text { Letter of } \\
\text { the Answer }\end{array}$ & $\begin{array}{l}\text { Q15 Last } \\
\text { Credit Amount }\end{array}$ & $\begin{array}{l}\text { Q9A Usage of Credit } \\
\text { from Family and } \\
\text { Friends }\end{array}$ & $\begin{array}{l}\text { Q9B Usage of } \\
\text { Government Grants and } \\
\text { Subsidies }\end{array}$ & $\begin{array}{l}\text { Q9C Usage of } \\
\text { Bank Loans }\end{array}$ & $\begin{array}{l}\text { Q9D Usage } \\
\text { of Leasing }\end{array}$ & $\begin{array}{l}\text { Q9E Usage of } \\
\text { Trade Credit }\end{array}$ \\
\hline A & $0-25,000 \mathrm{TL}$ & $\begin{array}{l}\text { Related but Did Not } \\
\text { Use }\end{array}$ & Related but Did Not Use & $\begin{array}{l}\text { Related but } \\
\text { Did Not Use }\end{array}$ & $\begin{array}{l}\text { Related but } \\
\text { Did Not Use }\end{array}$ & $\begin{array}{l}\text { Related but } \\
\text { Did Not Use }\end{array}$ \\
\hline B & $\begin{array}{l}25,001- \\
100,000 \mathrm{TL}\end{array}$ & Used & Used & Used & Used & Used \\
\hline C & $\begin{array}{l}100,001- \\
250,000 \mathrm{TL} \\
\end{array}$ & & & & & \\
\hline D & $\begin{array}{l}250,001- \\
1,000,000 \mathrm{TL} \\
\end{array}$ & & & & & \\
\hline$E$ & > 1 million TL & & & & & \\
\hline
\end{tabular}

In multiple regression analyses answer $A$ was taken as 1 , answer B was taken as 2, answer C was taken as 3 , answer D was taken as 4 , answer $\mathrm{E}$ was taken as 5 , answer $\mathrm{F}$ was taken as 6 , and answer $\mathrm{G}$ was taken as 7 . Therefore, while the significance of all variables can be determined, only the coefficients of numerical variables can be discussed.

\section{FINDINGS}

According to the survey results, most of SMEs in Turkey are family ventures, located in Marmara Region, established for more than 10 years, operating in industry area, target the domestic market, have less than 10 employees, hold low cash assets, and have a turnover level less than 500000 TL in 2016. 
According to the results of the questionnaire conducted and SAFE 2017, the second biggest issue for SMEs in Turkey is the access to finance, while this issue is the least important for SMEs in the EU; the increase in availability of financial sources for SMEs in the EU is much larger and they use them mostly for new investments, while SMEs in Turkey use them mostly for inventories; expenses for SMEs in Turkey such as labor and raw material cost increased more, which probably led to a decrease in profit and an increase in debts. Results show that bank loans are the most used type of finance for SMEs in Turkey. In addition, SMEs that are not able to get a bank loan indicated the highinterest rate as the main reason for it. On the other hand, according to most of the SMEs surveyed through SAFE 2017 in the EU, the highest usage of credit line in the preceding six months was reported. When credit amounts received are compared, most of the SMEs in Turkey received a credit between 25,001 - 100,000 TL, and most of the SMEs in the EU received a credit between 250,001 - 1,000,000 Euro in preceding six months. Out of this, it can be concluded that credit amounts approved to SMEs in the EU are much larger than the ones approved for SMEs in Turkey, giving better financial opportunities to SMEs in the EU to develop their business in starting years.

According to chi-square analyses at a $5 \%$ significance level, it is found that the amount of credit received by SMEs in Turkey is significantly affected by the age, the number of employees, turnover level, export level, and business area of the company $(p<0.05)$. The usage of loans from family and friends is significantly affected by the number of employees, export level, business area, and geographical location of the company $(p<0.05)$. The usage of government loans and incentives by SMEs in Turkey is significantly affected by age, the number of employees, and the export level of the company $(p<0.05)$. The usage of bank loans by SMEs in Turkey is significantly affected by the age, turnover level, export level, and the number of employees of the company $(p<0.05)$. The usage of leasing by SMEs in Turkey is significantly affected by the age, the number of employees, turnover level, export level, business area, and the partnership status of the company ( $p<$ 0.05). The usage of trade credit by SMEs in Turkey is significantly affected by the age, the number of employees, turnover level, export level, business area, partnership status, and geographical location of the company $(p<0.05)$.

According to multiple regression analyses at a $5 \%$ significance level, it is found that the amount of credit received by SMEs in Turkey is significantly affected by the age of the company positively with the coefficient of 0.26 , its number of employees positively with the coefficient of 0.33 , turnover level positively with the coefficient of 0.27 , and geographical location $(p<0.05)$. The usage of loans from family and friends is significantly affected by the turnover level of the company positively with the coefficient of 0.16 , and the age of the firm negatively by coefficient $-0.08(p<0.05)$. The usage of government loans and incentives by SMEs in Turkey was not significantly affected by the SME characteristics $(p<0.05)$. The usage of bank loans by SMEs in Turkey is significantly affected by the company's turnover level negatively with coefficient -0.07 , and the age of the firm negatively with coefficient $-0.09(p<0.05)$. The usage of leasing by SMEs in Turkey is significantly affected by the business area of the company $(p<0.05)$. The usage of trade credit by SMEs in Turkey was not significantly affected by SME characteristics ( $p<0.05)$.

\section{CONCLUSION}

The aim of this study is to compare status and changes in the access to finance of SMEs in Turkey and the EU. And additionally, to evaluate the access to finance of Turkish SMEs according to their associate status, location, business area, exports, liquid assets, and establishment time.

In developing the questionnaire used in this survey, some of the questions from the SAFE 2017 conducted in October 2017 on the EU SMEs, were modified. The questionnaire was sent to SMEs in Turkey through KOSGEB via e-mail. The response percentages obtained were compared with the response percentages from SAFE 2017. Also using analyses such as chi-square and multiple regression (SPSS) significant relations between answers of Turkish SMEs were determined.

According to the results of the questionnaire conducted and SAFE 2017, the second biggest issue for SMEs in Turkey is the access to finance, while this issue is the least important for SMEs in the EU; the increase in availability of financial sources for SMEs in the EU is much larger and they use them mostly for new investments, while SMEs in Turkey use them mostly for inventories; expenses for SMEs in Turkey such as labor and raw material cost increased more, which probably led to a decrease in profit and an increase in debts. According to multiple regression and chi-square analyses at a $5 \%$ significance level, it is found that the amount of credit received by SMEs in Turkey, and the usage of loans from family and friends are significantly affected by the age, number of employees, turnover level, export level, business area, and geographical location of the company. The usage of government loans and incentives by SMEs in Turkey is significantly affected by age, the number of employees, and the export level of the company. The usage of bank loans by SMEs in Turkey is significantly affected by the age, turnover level, export level, and the number of employees of the company. The usage of leasing and trade credits by SMEs in Turkey is significantly affected by the age, the number of employees, turnover level, export level, business area, geographical location, and the partnership status of the company.

There is a limited number of studies focusing on access to finance for SMEs in Turkey. They mostly tend to concentrate only on problematic supply-side factors and miss to show the significant relationship between demand-side factors, meaning SMEs' characteristics, and access to finance. At the same time, to our best knowledge, there is not any study directly comparing Turkish SMEs to the European SMEs except SAFE reports, which take only 300 SMEs in Turkey into consideration. On the other hand, this study takes 1,518 SMEs in Turkey into consideration and compares SMEs in Turkey and the EU according to their characteristics and access to finance.

\section{REFERENCES}

Abdulsaleh, A. M., \& Worthington, A. C. (2013). Small and medium-sized enterprises financing: A review of literature. International Journal of Business and Management, 8(14), 36-54. Retrieved from http://www.ccsenet.org/journal/index.php/ijbm/article/view/26253 
Abor, J. \&Biekpe, N. (2009). How do we explain the capital structure of SMEs in sub-Saharan Africa? Evidence from Ghana. Journal of Economic Studies, 36(1), 83-97. doi:10.1108/01443580910923812

Abor, J. (2008). Determinants of the capital structure of Ghanaian firms. African Economic Research Consortium Research Papers. $176,2-40$. Retrieved from https://www.africaportal.org/documents/5813/RP176.pdf

Ayadi, R. (2005). The new Basel capital accord and SME financing - SMEs and the new rating culture. Brussels, Belgium: Centre for European Policy Studies.

Beck, T., Demirgüç-Kunt, A. \& Martínez Pería, M. S. (2008). Bank financing for small and medium enterprises around the world: drivers, obstacles, business models, and lending practices (Policy Research Working Paper Series No. 4785). Retrieved from http://documents.worldbank.org/curated/en/706131468159334938/Bank-financing-for-smes-around-the-world-drivers-obstaclesbusiness-models-and-lending-practices

Beck, T., Demirguc-Kunt A. \&Maksimovic, V. (2004). Bank competition and access to finance: International evidence. Journal of Money, Credit, and Banking, 36(3), 627-648. Retrieved from

https://econpapers.repec.org/article/mcbjmoncb/v_3a36_3ay_3a2004_3ai_3a3_3ap_3a627-48.htm

Boachie-Mensah, F. O. \&Marfo-Yiadom, E. (2006). Entrepreneurship and small business management. Accra, Ghana: University Press.

Cakova, U. and Önder, Z. (2011). Capital structure determinants of Turkish small and medium enterprises in manufacturing industry (Unpublished Master thesis). Bilkent University. Ankara, Turkey.

Cassar, G. \& Holmes, S. (2003). Capital structure and financing of small and medium enterprises: Australian evidence. Journal of Accounting and Finance, 43(2), 123-147. doi: 10.1111/1467-629X.t01-1-00085

Cassar, G. (2004). The financing of business start-ups. Journal of Business Venturing, 19, 261-283. Retrieved from https://www.sciencedirect.com/science/article/abs/pii/S0883902603000296

De la Torre, A., Martinez Peria, M. S. \&Schmukler, S. (2010). Bank involvement with small and medium enterprises: Beyond relationship lending. Journal of Banking and Finance, 34, 2280-2293. Retrieved from http://siteresources.worldbank.org/DEC/Resources/Bank_Involvement_with_SMEs.pdf

Demirgüç-Kunt, A., \&Klapper, L. (2012). Measuring financial inclusion: the global Findex database. (Policy Research Working Paper No. 6025). Retrieved from https://openknowledge.worldbank.org/handle/10986/6042

Gajurel, D. P. (2005). Capital structure management in Nepalese enterprises (Unpublished Master thesis). Tribhuvan University, Kathmandu, Nepal.

Global Competitiveness Report. (2018). Chapter 2: Regional and Country Analysis. Retrieved from https://www.weforum.org/reports/theglobal-competitveness-report-2018

Jenkins, H., \& Hussain, M. (2014). An analysis of the macroeconomic conditions required for small and medium enterprises 'lending: The case of Turkey. Retrieved from https://cri-world.com/publications/qed_dp_261.pdf

Kira, A. R. (2013). Determinants of financing constraints in East African countries' small and medium enterprises. International Journal of Business and Management, 8(8), 49-68. Retrieved from https://pdfs.semanticscholar.org/7952/de10a66c1b9ce97f9be585486e04c6312e49.pdf

Kraemer-Eis, H. \& Lang, F. (2012). The importance of leasing for small and medium enterprises `finance. (European Investment Fund Working Paper No. 2012/2015). Retrieved from https://www.true-sale-

international.de/fileadmin/tsi_downloads/TSI_kompakt/eif_euromoney_importance-of-leasing-for-smes_fv.pdf

KüçükveOrtaÖlçekliiş̧letmeleriGeliştirmeveDesteklemeidaresiBaşkanlığı. (2012). Enhancing the competitiveness of SMEs In Turkey country report. Retrieved from http://en.kosgeb.gov.tr/Content/Upload/Dosya/SMESTRATEGYANDACTIONPLAN.docx

Mac an Bhaird, C. (2010). Resourcing small and medium sized enterprises: A financial growth life cycle approach. Heidelberg, Germany: Physica-Verlag.

Mahmud, S. \& Akin, T. (2019) SMEs' access to finance and choice of capital structure in Turkey. EgeAkademikBakışDergisi, 19(2), $277-291$. Retrieved from https://dergipark.org.tr/en/pub/eab/issue/44747/521579

Organization for Economic Co-operation and Development. (2004). Small and medium sized enterprises statistics: Towards a more systematic statistical measurement of SME behaviour. Retrieved from http://www.oecd.org/corporate/ca/corporategovernanceprinciples/31557724.pdf

Organization for Economic Co-operation and Development. (2016). Financing small and medium sized enterprises and entrepreneurs. Retrieved from https://www.oecd-ilibrary.org/industry-and-services/financing-smes-and-entrepreneurs_23065265

Organization for Economic Co-operation and Development. (2018). Education at a glance 2018. Retrieved from https://doi.org/10.1787/eag-2018-en

Ozar, S. (2004). Micro and small enterprises in Turkey: Uneasy development. (Research Report No. 0420). Retrieved from https://pdfs.semanticscholar.org/8625/4a390985505c12a157d084f04606b13764f8.pdf 
Ozer, A. C. (2016). A study on small and medium sized enterprises in Turkey with alternate financial sources from developing countries. Journal of Accounting \& Marketing, 5(1), 147-148. doi:10.4172/2168-9601.1000148

Rocha, R., Farazi, S., Khouri, R. \& Pearce, D. (2011). The status of bank lending to small and medium sized enterprises in the Middle East and North Africa region: The results of a joint survey of the union of Arab Bank and the World Bank. (World Bank Policy Research Working Paper No. 5607). Retrieved from http://documents.worldbank.org/curated/en/443431468046484153/The-status-of-bank-lending-to-SMES-inthe-Middle-East-and-North-Africa-region-the-results-of-a-joint-survey-of-the-Union-of-Arab-Bank-and-the-World-Bank

Sarapaivanich, N. (2006). The effect of demand-side factors on accessing external finance and performance of small and medium sized enterprises in Thailand (Unpublished PhD thesis). University of New England, Armidale, Australia.

Seker, M., \& Correa, P.G. (2010). Obstacles to growth for small and medium enterprises in Turkey. Retrieved from http://documents.worldbank.org/curated/en/162961468318313606/Obstacles-to-growth-for-small-and-medium-enterprises-in-Turkey

Titman, S. \& Wessels, R. (1988). The determinants of capital structure choice. Journal of Finance, 43(1), 1-19. Retrieved from https://pdfs.semanticscholar.org/c31e/2cbdd2b53bc1bd5682cec8a5577bbc4789ab.pdf

Turkish Statistical Institute. (2013). Small and medium size enterprises statistics-2013. Retrieved from http://www.kobi.org.tr/index.php/tanimi/stats

Wignaraja, G. \&Jinjarak, Y. (2015). Why small and medium sized enterprises do not borrow from banks? Evidence from People's Republic of China and Southeast Asia. (ADBI Working Paper No. 509). Retrieved from

http://www.adbi.org/files/2015.01.09.wp509.why.do.sme.not.borrow. from.banks.pdf

Willis-Ertür, S. \& Vader, J. (2015). More than meets the evil eye: Business practices and constraints of SMEs in Turkey. Medford, Oregon: Tufts University. 